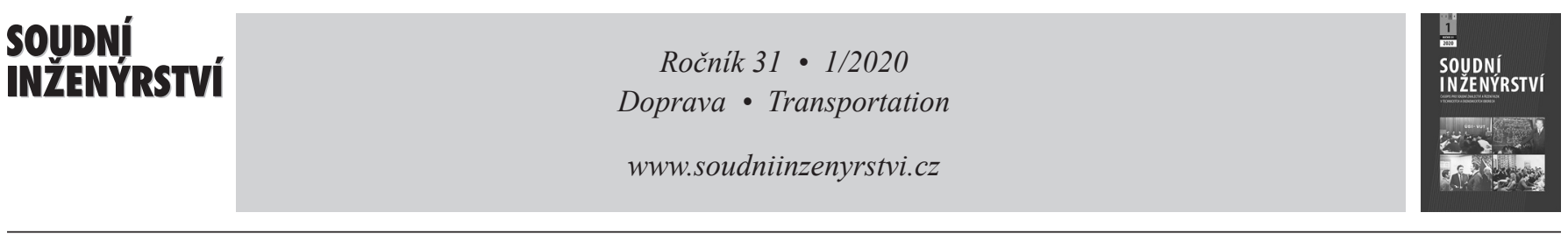

\title{
Soudní znalec a otázky spotřeby paliva vozidlových motorů
}

\author{
Authorized Expert and Question about Fuel Consumption of Vehicle Engines
}

Pavel Štěrba*

$T \ddot{U}$ SÜD Czech s.ro.

\begin{abstract}
Abstrakt
Článek pojednává o požadavcích na měření spotřeby paliva silničních vozidel, formátech údajů a vlivu vnějších podmínek na její velikost. Upozorňuje na typická úskalí při jejím vyhodnocování. Příspěvek byl prezentován na konferenci ExFoS 2020.
\end{abstract}

Klíčová slova: spotřeba paliva, bilance energie, jízdní odpory, pomocné pohony, předpisy EHK, hmotnostní měření, objemové měření, emisní přepočet, hybridní vozidla.

\section{1. ÚVOD}

V odborné automobilové praxi, včetně znalecké, se dříve či později setkáme s požadavkem na ověření spotřeby paliva některého vozidla. Nejčastěji se bude jednat o nespokojenost uživatele osobního automobilu s hodnotou spotřeby, deklarovanou v technickém průkazu, ale ojediněle se můžeme setkat i s požadavkem hodnocení provozní spotřeby užitkového vozidla vưči nějaké hodnotě, deklarované výrobcem.

\section{LEGISLATIVNÍ POŽADAVKY}

Mezinárodní předpisová základna standardizuje přístup ke zjišstování spotřeby paliva, coby srovnávacího kritéria ekonomiky provozu mezi jednotlivými vozidla, již od prvních okamžiků, co byla vytvořena počátkem 70 let. Nejprve byly požadavky stanoveny pouze pro osobní automobily, postupem doby se rozšiřovaly i na další druhy vozidel. Mimo požadavky mezinárodní předpisové základny existují též nejrůznější národní normy nebo oborové metodiky.

\subsection{Uvádění spotřeby paliva podle kategorií vozidel}

Termíny uvádění spotřeby paliva dle mezinárodních požadavků jsou přehledně uvedeny v tab. 1. Data uvádění nejsou zcela fixní, nebot'

\begin{abstract}
This article deals with fuel consumption measurements at road vehicles, format of data and influence of external conditions onto results. Article extra highlight onto typical problems during its interpretation.
\end{abstract}

Keywords: fuel consumption, energy balance, vehicle road load, auxiliary devices, ECE Regulation, mass measurements, volumetric measurements, emission to fuel consumption conversion, hybrid vehicles.

Tab. 1 Vyžadování údajů spotreby paliva. Tab. 1 Requesting of fuel consumptions data.

\begin{tabular}{ll}
\hline Vozidlo & termín \\
\hline M1 & vždy (1970) \\
N1, provozní hmotnost do $1305 \mathrm{~kg}$ & 1.1 .2006 \\
N1, provozní hmotnost přes $1305 \mathrm{~kg}$ & 1.1 .2008 \\
L3e, L4e, L5e, L7e & 1.1 .2017 \\
L1e, L2e, L6e & 1.1 .2018 \\
N2, N3 (vybrané druhy) & 1.7 .2019 , dále v půlročních \\
& intervalech \\
\hline
\end{tabular}

existují souběhy platnosti některých předpisů, instituty doprodejů vozidel a výjimky v aplikaci.

Vedle spotřeby paliva celých vozidel se uvádí rovněž křivka měrné spotřeby paliva samotného spalovacího motoru, udávající v podstatě míru jeho účinnosti při plném zatížení. Tato křivka je součástí pouze schvalovací nebo homologační dokumentace, do technického průkazu se neuvádí.

\subsection{Mezinárodní předpisová základna}

Mezinárodní předpisová základna, stanovující požadavky na způsob měření, je dnes již poměrně rozsáhlá a komplikovaná. Uved'me si pro orientaci alespoň její základní přehled: 


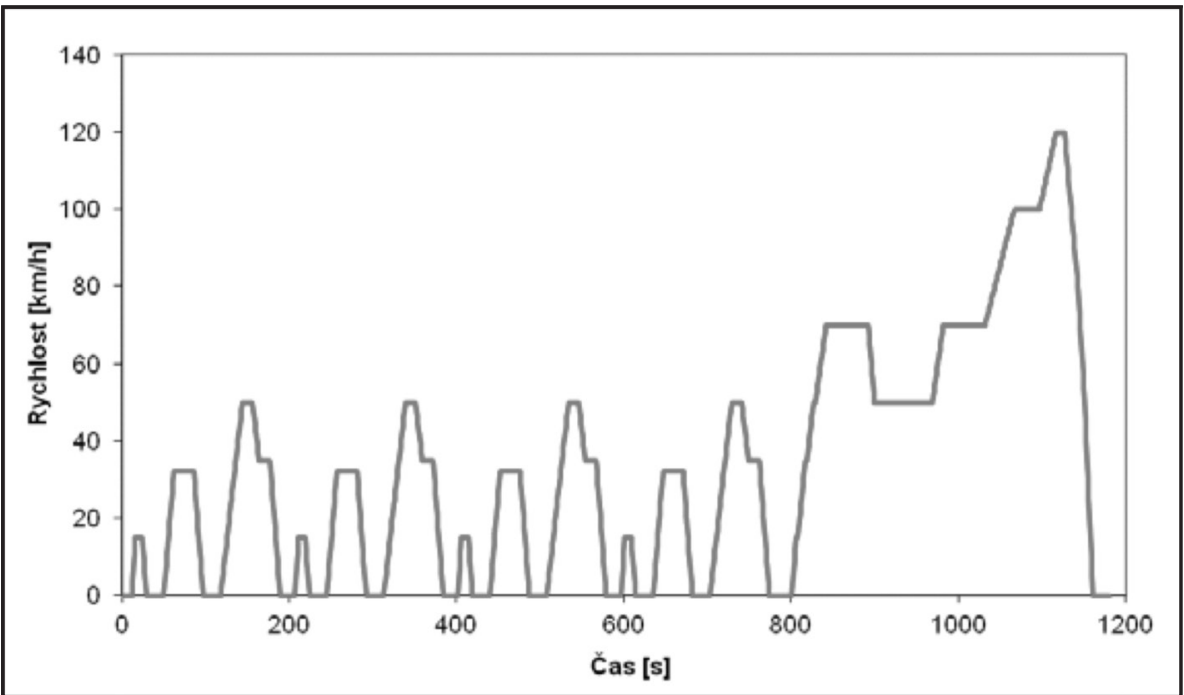

Obr. 1 Městská a mimoměstská fáze měrícího cyklu EHK 101.

Fig. 1 Urban and extra urban phase of ECE 101 testing cycle.

- EHK 15 - dnes již zrušený předpis, který souhrnně definoval požadavky na emise škodlivin ve výfukových plynech, způsoby měření výkonu motoru a způsob měření spotřeby paliva. Platil v letech 1970-1989. Údaj se uváděl ve tvaru 90/120/Město, tj. při ustálené jízdě rychlostmi $90 \mathrm{~km} \cdot \mathrm{h}^{-1}$, $120 \mathrm{~km} \cdot \mathrm{h}^{-1}$ a v městském provozu.

- EHK 84 - rovněž zrušený předpis, definující způsob měření spotřeby paliva. Platil v letech 1990 až cca 1996. Údaj se uváděl shodně ve tvaru 90/120/Město.

- EHK 85 - předpis, definující požadavky na měření výkonu, točivého momentu a měrné spotřeby paliva samotných motorů.
- EHK 101 - předpis platný dodnes, byt' Evropská unie jej v posledních letech využívá pouze částečně. Údaj se uvádí ve tvaru Město/Mimoměsto/Kombinace. Umožňuje pouze měření v laboratoři.

- 134/2014/ES - prováděcí nařízení ES, stanovující požadavky na měření emisí a spotřeby paliva vozidel kategorie. L (motocykly).

- 692/2008/ES - prováděcí nařízení ES, stanovující požadavky na měření emisí a spotřeby paliva vozidel kategorií M a $\mathrm{N}$ do provozní hmotnosti $2585 \mathrm{~kg}$ (extenze typu až do $2815 \mathrm{~kg}$ ).
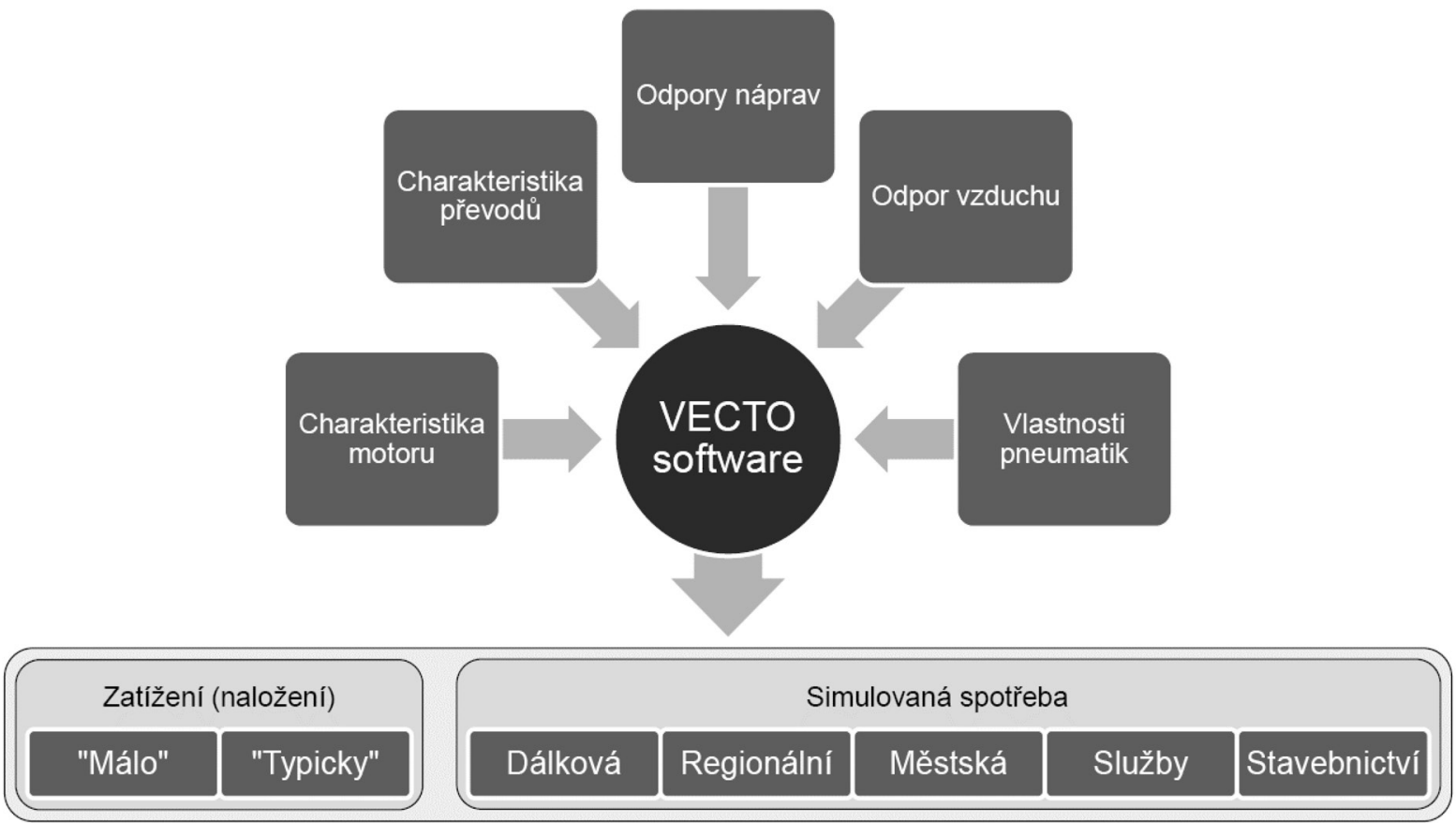

Obr. 2 Princip simulace spotřeby dle 2017/2400/ES.

Fig. 2 Simulation principle of fuel consumption according to 2017/2400/EC. 


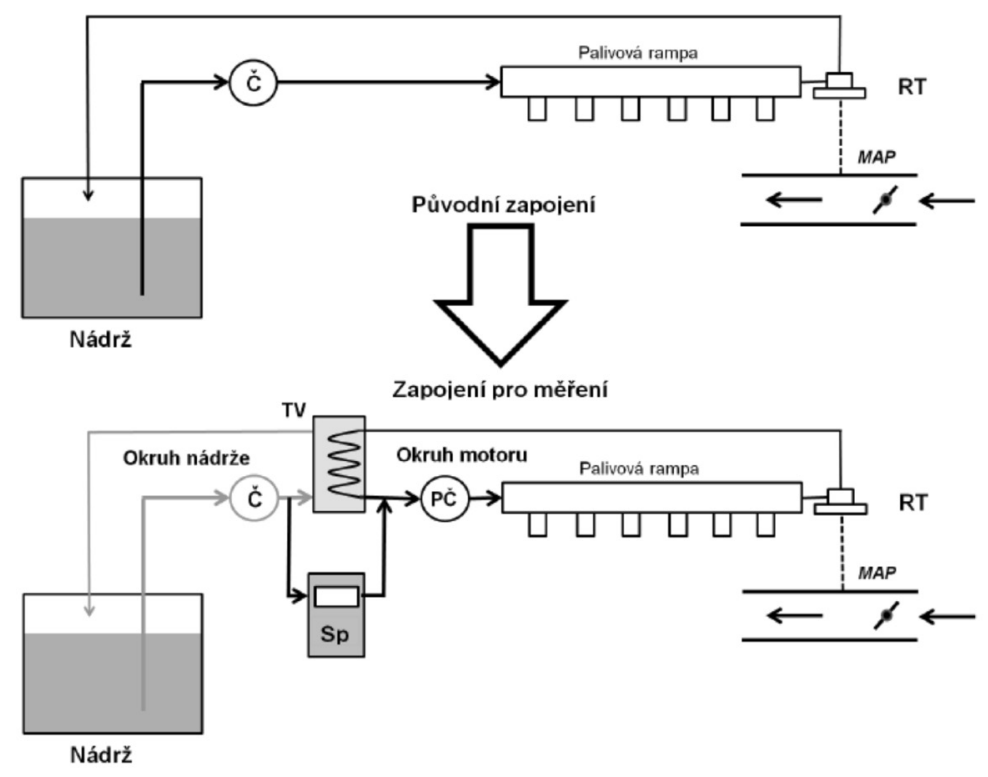

Obr. 3 Typické zapojeni objemového průtokoméru do palivového okruhu.

Fig. 3 Typical installation of volumetric flow device in the fuel system with circulation.

- 2017/2400/ES - prováděcí nařízení ES, stanovující požadavky simulace spotřeby paliva vozidel kategorií M a $\mathrm{N}$ s provozní hmotností přes $2585 \mathrm{~kg}$.

\subsection{Požadavky mimo legislativu}

Mimo oficiální legislativu se lze rovněž setkat s požadavky dle různých normativů a metodik, např. normy DIN, ČSN, CUNA, PLN či metodiky UITP SORT. Ty se používají v rámci deklarace provozních parametrů pro účely různých výběrových řízení

\section{ZPU゚SOBY ZJIŠŤOVÁNÍ SPOTŘEBY PALIVA}

V dnešní době se používají 3 základní způsoby zjišt’ování spotřeby paliva:

- objemové měření,

- hmotnostní měření,

- výpočet $\mathrm{z}$ emisí.

Pro segment nákladních automobilů se nově zavádí zjišt’ování spotřeby pomocí simulací prostřednictvím centralizovaného software, vyvinutého na zakázku pro Evropskou komisi.

\subsection{Objemové měření}

Využivá se zejména při silničních zkouškách pro kapalná paliva a dále v laboratořích při zkouškách samotných motorů. Nese s sebou komplikovanější zástavbu u vozidel (motorů) s cirkulací paliva a je nutno dbát na pečlivé odvzdušnění palivového systému. Výsledky je nezbytné korigovat podle teploty paliva v místě měření (obr. 3).

\subsection{Hmotnostní měření}

Hlavní určení je pro prímé fyzické měření spotřeby u plynových motorů a rovněž v laboratořích při zkouškách samotných motorů. Pro motory s cirkulací paliva je nutné použít dva takové př́stroje. Typickým představitelem používaných přístrojů je Coriolisův hmotnostní průtokoměr, u jehož instalace se však musíme vyvarovat působení př́ípadných externích vibrací (obr. 4).

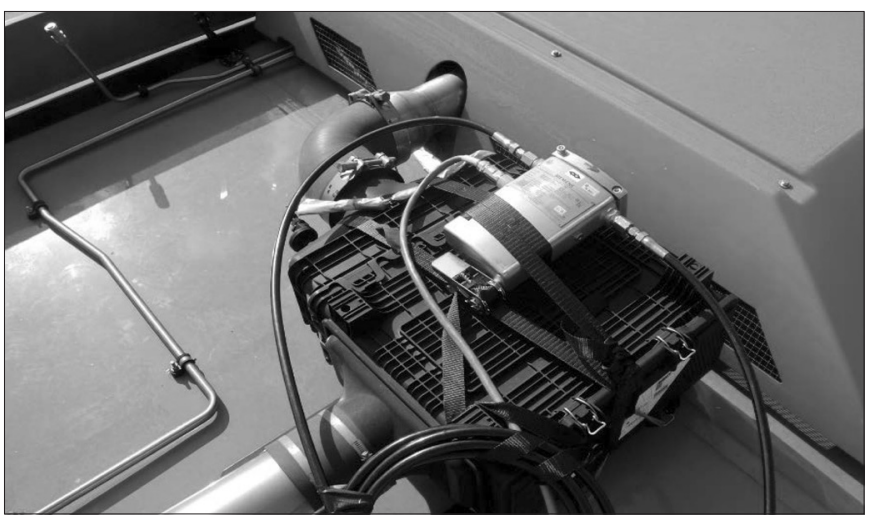

Obr. 4 Instalace Coriolisova hmotnostního průtokoměru na CNG autobusu.

Fig. 4 Installation of Coriolis mass flow device in the CNG bus.

\subsection{Výpočet z emisí}

V současnosti je vyhrazeno pro homologační zkoušky malých vozidel, př́padně pro kontroly shodnosti výroby. Hlavní výhodou je, že odpadají zásahy do palivové soustavy. Výpočet se provádí pomocí tzv. uhlíkové bilance, u které je nutné znát vlastnosti používaného paliva.

\section{VLIVY NA SPOTŘEBU PALIVA}

At' již při standardizovaných zkouškách nebo v reálném provozu existuje řada faktorů, které mají na výsledek spotřeby paliva často podstatný vliv. Neuvědomění si těchto vlivů potom může vést k poukazování na odlišné provozní hodnoty, případně na výsledek kontrolního měření, oproti hodnotám uváděnými výrobcem. 


\subsection{Teplota paliva}

Při objemovém měření je nezbytné provádět korekci na teplotu paliva, kterou musíme snímat v místě měření. Tu lze vyjádřit jako

$$
V_{\text {corr }}=V_{\text {meas }}(1-\alpha(T-20)) \text {, }
$$

kde:

$\alpha \quad$ je součinitel objemové roztažnosti paliva $\left(0,001 \mathrm{~K}^{-1}\right)$,

$V_{\text {corr }} \quad$ korigovaný objem spotřebovaného paliva,

$V_{\text {means }} \quad$ změřený objem spotřebovaného paliva,

$T$ teplota paliva $\mathrm{v}$ místě měření.

\subsection{Výhřevnost paliva}

Při shodných provozních podmínkách se nám bude výše spotřeby paliva měnit $\mathrm{v}$ závislosti na výhřevnosti paliva. To má význam zejména u lihobenzínových směsí (s rostoucím podílem lihu klesá výhřevnost směsného paliva) a plynových pohonů (podíl metanu v zemním plynu se může pohybovat mezi $85-100 \%$, rovněž v případě LPG mohou být jednotlivé různě výhřevné složky včetně povolených cizích příměsí v různých poměrech).

Homologační zkoušky, jejichž výsledky prezentuje výrobce, se provádějí s tzv. referenčním palivem přesně daného složení. Zde až do emisní úrovně Euro4 docházelo k paradoxu, že výrobci mohli prezentovat údaje naměřené s čistým benzínem, zatímco u čerpacích stanic se již distribuovala lihobenzínová směs, která obsahovala nominálních $5 \%$ lihu a jejíž výhřevnost byla samozřejmě nižší. Složení referenčních plynů (LPG, CNG) je od norem platných pro čerpací stanice vzdáleno ještě více.

\subsection{Princip uvádění hodnot výrobcem}

Většina výrobců plně využivala znění předpisové základny, které umožňovalo deklarovat de facto libovolnou hodnotu, pokud hodnota naměřená při kontrolním testu nebude odlišná o více než $4 \%$. Tato tolerance byla původně zamýšlená jako tolerance rozptylu měření, avšak při dobré shodnosti výroby a rostoucí opakovatelnosti zkoušek v laboratorních podmínkách výrobci deklarovali do technických průkazů výsledky o 4 \% nižší, než jaké prokazovali při reálných měřeních.

\subsection{Hmotnost vozidla}

V případě měřní podle požadavků EHK 101, tj. cca do r. 2018, se vozidla pro třídila do hmotnostních tříd s rozestupem cca $100 \mathrm{~kg}$. $\mathrm{V}$ některých př́ípadech tak situace přímo sváděla $\mathrm{k}$ tomu vozidlo odlehčit jen o několik kilogramů, které by se na výsledku prakticky neprojevily, což ovšem vedlo k přeřazení vozidla do třídy o $100 \mathrm{~kg}$ lehčí a různé „zelené“ nebo „modré“ varianty modelových řad s mírně optimističtějšími výsledky byly na světě.

\subsection{Jízdní odpory vozidla, počasí}

Vliv jízdních odporů vozidla na spotřebu je do určité míry proporcionální. Jízdní odpory vozidla jsou obvykle konstrukčně dány, nicméně může dojít $\mathrm{k}$ jejich změně např. chybným seřízením podvozkových orgánů či závadou na vozidle. Dále dojde k jejich změně vlivem naložení (zatížení) vozidla, změnou čelní plochy (stř̌ešní nosiče, střešní boxy, spoilery), montáží různých doplňků, změnou pneumatik či připojením přívěsu.

Poněkud opomíjeným, avšak logickým vlivem je působení počasí. Nejpodstatnější, zejména ve vyšších rychlostech, je působení větru, ovšem zcela bez vlivu nejsou ani okolní teplota a barometrický tlak. Přibližně do r. 1996, kdy byly přípustné silniční zkoušky, se oficiálně aplikovaly speciální korekce ve tvaru

$$
F C_{\text {corr }}=F C\left(\frac{O_{\text {valeni }}}{O_{\text {celkovy }}}(1+0,0036(T-20))-\frac{O_{\text {aerodynamicky }}}{O_{\text {celkovy }}} \frac{\rho_{0}}{\rho}\right),
$$

kde:

$F C_{\text {corr }}$ korigovaná hodnota spotřeby paliva,

$F C$ naměřená hodnota spotřeby paliva,

$O$ reprezentuje složky jízdního odporu vozidla,

$T \quad$ teplota okolí,

$\rho_{0} \quad$ hustota vzduchu při standardních podmínkách $\left(1000 \mathrm{hPa}, 20^{\circ} \mathrm{C}\right)$,

$\rho \quad$ hustota okolního vzduchu.

Tato korekce není stálá, je závislá na rychlosti jízdy vozidla a její aplikace na jiný, než ustálený režim jízdy je nutno řešit bud'to kontinuální integrací korigovaného průtoku paliva nebo selektivně váženým průměrem. Rovněž tak je nutné znát křivku jízdního odporu vozidla, konkrétně poměr valivé a aerodynamické složky. Orientačně lze konstatovat, že u běžného osobního vozidla způsobí okolní teploty kolem $0{ }^{\circ} \mathrm{C}$ zvýšení spotřeby paliva dle charakteru provozu o cca $5-10 \%$ oproti teplotám okolí $20{ }^{\circ} \mathrm{C}$. Vliv změn barometrického tlaku činí potom při rychlostech jízdy do $90 \mathrm{~km} \cdot \mathrm{h}^{-1}$ méně než $1 \%$.

\subsection{Pomocné pohony}

Vliv pomocných pohonů může být značný, zejména jedná-li se o pohony s velkým odběrem, např. klimatizaci či vzduchové kompresory. Předpisová základna stanovuje, že veškeré pohony, pokud nejsou nezbytné pro běh motoru či vozidla (napřr. chlazení, vzduchové kompresory), jsou při měření vypnuty. Předpisy však umožňují v určitých situacích i demontáž hnacích elementů (např. hnacích řemenů), což již nelze přirovnat k obvyklému uživání vozidla. Hlubší rozbor by byl již nad rámec tohoto příspěvku.

\subsection{Styl jízdy a užívání vozidla}

Způsob užívání vozidla představuje podstatný, ovšem obtížně odhadnutelný faktor. Nemá smysl na tomto místě připomínat zásady hospodárné jízdy, avšak existuje celá řada situací a jízdních režimů, kdy na výsledek, at' je jakkoli negativní nemá řidič podstatný vliv. Jedná se zejména o jízdy na krátké vzdálenosti, různé rozvážkové služby, jízdu v terénu či hustém městském provozu. V takových případech nelze srovnávat reálné provozní hodnoty s hodnotami deklarovanými výrobcem a nezbývá než např. pro stanovení provozních nákladů provést specifické měření v konkrétním provozu.

\section{HYBRIDNÍ POZNÁMKA}

V souvislosti s rostoucím podílem hybridních vozidel nemůžeme opomenout dvě zásadní připomínky. První připomínka se týká teploty okolí, potažmo přenesené na teplotu baterií. Po nastartování takového vozidla za nízkých teplot okolí nemůžeme od hybridního ústrojí čekat optimální vlastnosti, nebot' schopnost trakčních baterií podávat odpovídající výkon a zejména rekuperovat je závislá na teplotě. Optimálních vlastností dosahuje hybridní ústrojí při 
teplotách mezi cca $20-35^{\circ} \mathrm{C}$. Při vyšších teplotách se omezuje výkon baterií kvůli přehřívání, při nižších klesá přirozeným způsobem. Jako určitý mezník můžeme označit teplotu kolem $5{ }^{\circ} \mathrm{C}$, pod kterou má již baterie omezenou schopnost nabíjení a tím i rekuperace energie. Provozem se baterie zahřejí, ale zlepšení vlastností nastává v zimních měsících až cca po 30-60 minutách jízdy.

Druhá, možná ještě zásadnější připomínka se týká tzv. plugin hybridů. Zde se doposud udávala spotřeba ve 3 režimech a v každém z nich ve fázi městské, mimoměstské a kombinované:

- režim A - start měření s plně přednabitými trakčními bateriemi,

- režim B - start bez přednabití, tj. běžný hybridní režim,

- režim „váženého průměru“, který se posléze používá pro hodnocení vozidla v rámci různých daňových úlev apod.

Zavádějící je právě poslední údaj, tzv. váženého průměru, který se vypočitává tak, že se vezme podíl spotřeby v režimu A (obvykle je to nulová spotřeba) s váhovým kritériem maximálního možného dojezdu na elektřinu a $\mathrm{k}$ tomu podíl spotřeby $\mathrm{v}$ režimu $\mathrm{B}$, ovšem s váhovým kritériem paušálních $25 \mathrm{~km}$. Jinými slovy, vychází se $\mathrm{z}$ předpokladu, že vozidlo neustále jezdí na elektřinu a $\mathrm{v}$ př́ípadě, že se baterie vybijí, ujede řidič nejvýše $25 \mathrm{~km}$, než vozidlo znovu nabije. To ovšem realitě skutečného provozu vůbec neodpovídá.

\section{ZÁVĚR}

Problematika měření a zejména vyhodnocování spotřeby paliva včetně srovnávání provozních hodnot s údaji výrobce je poměrně rozsáhlá a můžeme se i v dobré víře snadno dopustit špatného úsudku. Je tedy nezbytné pečlivě zvážit všechny provozní okolnosti měření a vlivy vnějšího okolí pro zachování maximální objektivity.

\section{LITERATURA}

[1] ŠTĚRBA, P. Problematika měreni spotřeby paliva a vliv pomocných pohonů na její velikost v autobusech hromadné dopravy. Disertační práce, Mendelova univerzita v Brně, Brno, 2014, $141 \mathrm{~s}$.

[2] PAPOUŠEK, M., ŠTĚRBA, P. Diagnostika spalovacich motorů. Computer Press, Brno, 2007, 223 s. ISBN 978-80-251-1697-5.

[3] EHK OSN č. 84 Jednotná ustanovení pro homologaci osobnich automobilu se spalovacím motorem z hlediska spotřeby paliva. Ženeva, Švýcarsko, 1995, 49 s.

[4] EHK OSN č. 101 Jednotná ustanovení pro homologaci osobnich automobilů poháněných výhradně spalovacím motorem nebo poháněných hybridním elektrickým hnacím ústrojím z hlediska měreni oxidu uhličitého a spotřeby paliva a/nebo měreni spotřeby elektrické energie a jízdního dosahu na elektřinu, dále vozidel kategorii M1 a N1, poháněných výhradně elektrickým hnacím ústrojím z hlediska měreni spotřeby elektrické energie a jizdního dosahu na elektřinu. Ženeva, Švýcarsko, 2012, $101 \mathrm{~s}$.

[5] ŠTĚRBA, P. Soudní znalec a otázky spotřeby paliva vozidlových motorů. ExFoS 2020, ÚSI VUT v Brně, 2020, s. 210-217. ISBN 978-80-214-5829-1.

\section{Správná citace:}

ŠTĚRBA, P. Soudní znalec a otázky spotřeby paliva vozidlových motorů. Soudní inženýrství, 2020, 31(1), 17-21.

DOI: http://dx.doi.org./10.13164/SI.2020.1.17. ISSN 1211-443X. 